\title{
Penerapan Metode AHP Dan SAW Untuk Penentuan Kenaikan Jabatan Karyawan
}

\author{
Diah Permatasari* $^{1}$, Dewi Sartika ${ }^{2}$, Suryati $^{3}$ \\ ${ }^{1,2}$ Universitas Indo Global Mandiri; JL.Jend.Sudirman KM.4 N0.629 \\ ${ }^{3}$ Jurusan Teknik Informatika Fakultas Ilmu Komputer, UIGM, Palembang \\ e-mail: *11 diahpermatasari979@gmail.com, ${ }^{2}$ dewi.sartika@uigm.ac.id, \\ ${ }^{3}$ suryati@uigm.ac.id
}

\begin{abstract}
Abstrak
Penelitian ini bertujuan untuk menentukan kenaikan jabatan karyawan pada Dinas Kesehatan Provinsi Sumatera Selatan dengan menggunakan metode AHP (Analytic Hierarchy Prcess) dan SAW (Simple Additive Wieght). Metode AHP digunakan untuk menentukan bobot dari setiap kriteria, sedangkan metode SAW digunakan untuk menentukan rangking kenaikan jabatan karyawan. Proses kenaikan jabatan ini dibuat menggunakan bahasa pemrograman microsoft visual studio. Pengujian yang dilakukan pada penelitian ini yaitu pengujian blackbox dan pengujian akurasi. Hasil Pengujian black box menunjukkan bahwa sistem dapat berjalan dengan baik sesuai dengan fungsinya, sedangkan pengujian akurasi diuji dengan membandingkan hasil dari perhitungan Dinas Kesehatan, dengan hasil perhitungan metode $A H P$, hasil perhitungan metode SAW dan hasil perhitungan AHP \& SAW dalam menentukan kenaikan jabatan karyawan. Hasil pengujian akurasi pada 3 kasus uji tersebut diperoleh bahwa metode AHP \& SAW lebih baik dibangdingkan metode AHP dan metode SAW. Hasil akurasi metode AHP dan SAW pada kasus 1 adalah 100\%, pada kasus 2 adalah 100\%, dan pada kasus 3 adalah $50 \%$.
\end{abstract}

Kata kunci: Analytic Hierarchy Process, Simple Additive Weight,Kenaikan Jabatan Karyawan

\begin{abstract}
This study aims to determine the promotion of employees at the Dinas Kesehatan South Sumatera by using the AHP (Analytic Hierarchy Process) dan SAW (Simple Additive Wieght) methods. The AHP method is used to determine the weight of each criterion, while the SAW method is used to determine the rank of employee promotion. This promotion process is made using the Microsoft Visual Studio programming language. The test in this study carried out using blackbox testing methods and accuray testing. The black box test results show that the system can run well according to it's function, and then the accuracy testing is tested by comparing the results of the calculation from Dinas Kesehatan office. From the ealculation result of the AHP method, SAW method, and AHP \&SAW method can be concluded, AHP \& $S A W$ methods are better then AHP or SAW methods. The accuracy of the AHP and SAW method in case 1 is $100 \%$, in case 2 is $100 \%$, and in case 3 is $50 \%$.
\end{abstract}

Keyword: Analytic Hierarchy Process, Simple Additive Weight, Kenaikan Jabatan Karyawan 


\section{PENDAHULUAN}

$\mathrm{K}$ enaikan jabatan adalah penghargaan yang diberikan atas prestasi kerja dan pengabdian Aparatur Sipil Negara, serta sebagai dorongan untuk lebih meningkatkan prestasi kerja dan pengabdiannya [1]. Kenaikan jabatan PNS di bagi menjadi 2 yaitu jabatan fungsional dan jabatan struktural. Jabatan fungsional dilihat dari angka kredit, sedangkan jabatan struktural dilihat dari kinerjanya. Proses kenaikan jabatan struktural pada Dinas Kesehatan masih menggunakan rapat yang diketuai oleh pimpinan beserta kepala subbag dan kepala bidang. Salah satu usaha untuk meminimalisir cara kolusi dan nepotime adalah dengan penggunaan sistem penunjang keputusan dalam menentukan jabatan karyawan. Kriteria-kriteria yang digunakan dalam menentukan kenaikan jabatan yaitu golongan, eselon terakhir, jabatan terakhir dan pendidikan terakhir.

Metode yang dapat digunakan untuk membuat suatu Sistem Penunjang Keputusan diantaranya adalah metode AHP dan SAW. Kelebihan metode AHP (Analytic Hierarchy Process) adalah AHP membuat permasalahan yang luas dan tidak terstruktur menjadi suatu model yang fleksibel dan mudah dipahami, Sedangkan kelemahan metode AHP adalah Ketergantungan model AHP pada input utamanya. Input utama ini berupa persepsi seorang ahli sehingga dalam hal ini melibatkan subyektifitas sang ahli [2]. Kelebihan metode SAW (Simple Additive Weight) adalah Menentukan nilai bobot untuk setiap atribut kemudian dilanjutkan dengan proses perankingan yang akan menyeleksi alternatif terbaik dari sejumlah alternatif, Penilaian akan lebih tepat karena didasarkan pada nilai kriteria dari bobot preferensi yang sudah ditentukan, Sedangkan kelemahan metode SAW adalah digunakan pada pembobotan lokal [3]. Berdasarkan kelebihan dan kelemahan tersebut akan diterapkan kedua metode dalam menentukan kenaikan jabatan karyawan pada Dinas Kesehatan (Dinkes) Provinsi Sumatera Selatan. Metode AHP akan digunakan untuk penentuan bobot kriteria kenaikan jabatan, sedangkan metode SAW akan digunakan untuk nilai bobot setiap atribut kriteria dan mengolah data perhitungan seleksi kenaikan jabatan karyawan sehingga akan diperoleh hasil yang menjadi keputusan akhirnya.

\section{METODE PENELITIAN}

a. Tempat Penelitian

Penelitian ini dilakukan pada Dinas Kesehatan (Dinkes) Provinsi Sumatera Selatan yang beralamat di jln.Dr.M.Ali Komp.RSUD Palembang.

\section{b. Metode Pengumpulan Data}

Metode pengumpulan data yang dilakukan penulis dalam rangka mendukung tercapainya pengumpulan data dengan melakukan kegiatan:

1. Observasi

Observasi merupakan teknik pengumpulan data melalui proses pengamatan secara langsung dan mencatat secara sistematis terhadap kegiatan yang diteliti yaitu proses penentuan kenaikan jabatan yang berlangsung selama ini.

2. Wawancara

Pada tahapan ini dilakukan wawancara dengan pihak yang berwenang dalam penentuan proses kenaikan jabatan terkait kriteria-kriteria serta bobotnya yang dinilai. Kriteria tersebut terdiri dari 4 kriteria yaitu golongan, eselon terakhir, jabatan terakhir, dan pendidikan terakhir. 


\section{c. Metode AHP}

Menurut Satriani et.al AHP merupakan model pendukung keputusan yang menguraikan masalah multifaktor atau multikriteria yang kompleks menjadi suatu bentuk hierarki [4]. Sedangkan menurut Alit Metode AHP adalah sebuah kerangka untuk mengambil keputusan dengan efektif atas persoalan yang kompleks dengan menyederhanakan dan mempercepat proses pengambilan keputusan dengan memecahkan persoalan tersebut kedalam bagian-bagiannya, menata bagian atau variabel ini dalam suatu susunan hirarki [5].

Dalam penelitian ini metode AHP digunakan untuk menentukan bobot dari kriteriakriteria yang telah ditetapkan di Dinas Kesehatan (Dinkes) Provinsi Sumatera Selatan. Kriteriakriteria yang digunakan adalah golongan, eselon terakhir, jabatan terakhir dan pendidikan terakhir. Langkah-langkah dalam menggunakan metode AHP [4] adalah:

1. Mendefinisikan masalah dan menentukan solusi yang diinginkan, lalu menyusun hirarki dari permasalahan yang dihadapi. Hirarki penentuan kenaikan jabatan dapat dilihat pada gambar 1.

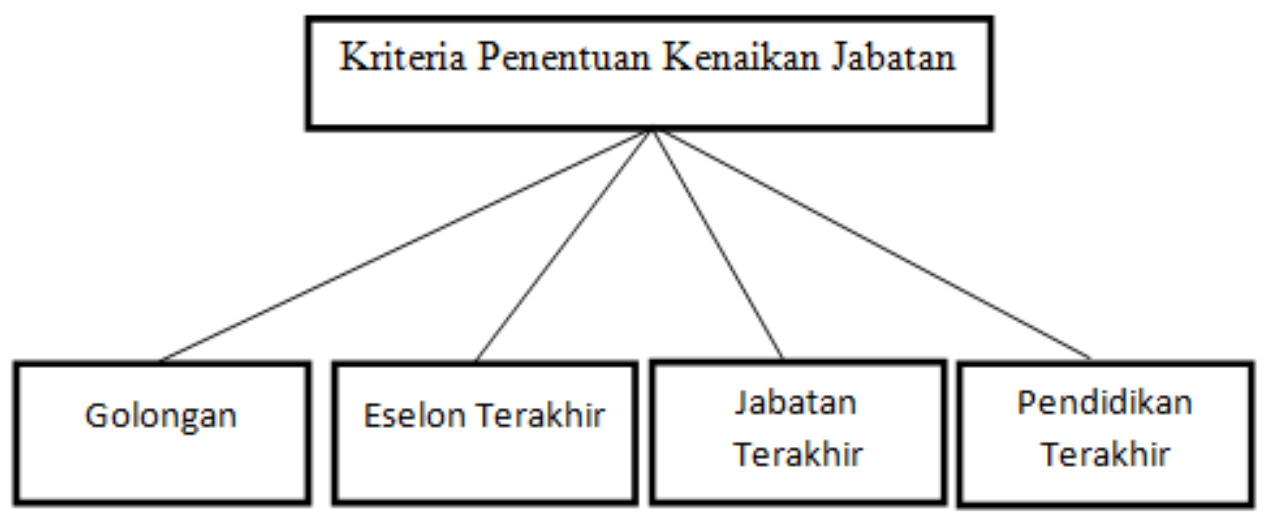

Gambar 1. Hirarki Penentuan Kenaikan Jabatan

2. Menentukan prioritas elemen dengan membuat matriks perbandingan berpasangan yang diisi dengan bilangan untuk merepresentasikan kepentingan relatif antar elemen matriks skala perbandingan berpasangan dapat dilihat pada tabel 2.1. Pada penelitian ini matriks perbandingan berpasangan diisi oleh karyawan dinas kesehatan. Untuk nilai golongan ke eselon adalah $1 / 2$ didapat dari golongan ke golongan adalah 1 dan eselon ke golongan 2 jadi hasilnya adalah 1/2. Matriks perbandingan berpasangan dapat dilihat pada tabel 1 .

Tabel 1. Matriks Perbandingan Berpasangan

\begin{tabular}{|l|c|c|c|c|}
\hline \multicolumn{1}{|c|}{ Kriteria } & Golongan & $\begin{array}{c}\text { Eselon } \\
\text { terakhir }\end{array}$ & $\begin{array}{c}\text { Jabatan } \\
\text { terakhir }\end{array}$ & $\begin{array}{c}\text { Pendidikan } \\
\text { terakhir }\end{array}$ \\
\hline Golongan & 1 & $1 / 2$ & $1 / 5$ & $1 / 4$ \\
\hline Eleselon terakhir & 2 & 1 & $1 / 2$ & $1 / 4$ \\
\hline Jabatan terakhir & 5 & 2 & 1 & $1 / 2$ \\
\hline Pendidikan terakhir & 4 & 4 & 2 & 1 \\
\hline
\end{tabular}

3. Normalisasi matriks

a. Menjumlahkan nilai dari setiap kolom pada matriks perbandingan berpasangan yang ditunjukkan pada persamaan berikut ini.

$$
n=\sum_{i=0}^{Z} x_{i j}(1)
$$


Keterangan :

$\mathrm{n}=$ hasil penjumlahan tiap kolom

$\mathrm{z}=$ banyak alternatif

$\mathrm{I}=1,2,3, \ldots, \mathrm{Z}$

$\mathrm{x}=$ nilai tiap cell $/$ gabungan antara kolom dan baris

Contoh perhitungan :

$\mathrm{n}=1+2+5+4=12$

Lakukan perhitungan sampai kolom terakhir / Pendidikan terakhit. Berikut hasil penjumlahan nilai dari setiap kolom pada matriks perbandingan berpasangan yang dapat dilihat pada tabel 2 .

Tabel 2. Hasil Penjumlahan Nilai dari Setiap Kolom

\begin{tabular}{|l|c|c|c|c|}
\hline \multicolumn{1}{|c|}{ Kriteria } & Golongan & $\begin{array}{c}\text { Eselon } \\
\text { terakhir }\end{array}$ & $\begin{array}{c}\text { Jabatan } \\
\text { terakhir }\end{array}$ & $\begin{array}{c}\text { Pendidikan } \\
\text { terakhir }\end{array}$ \\
\hline Golongan & 1 & 0,5 & 0,2 & 0,25 \\
\hline Eleselon terakhir & 2 & 1 & 0,5 & 0.25 \\
\hline Jabatan terakhir & 5 & 2 & 1 & 0,5 \\
\hline Pendidikan terakhir & 4 & 4 & 2 & 1 \\
\hline $\mathbf{N}$ & $\mathbf{1 2}$ & $\mathbf{7 , 5}$ & $\mathbf{3 , 7}$ & $\mathbf{2}$ \\
\hline
\end{tabular}

b. Membagi setiap nilai kolom dengan total kolom yang bersangkutan untuk memperoleh normalisasi matriks yang ditunjukkan pada persamaan dibawah ini.

$m=\frac{x_{i j}}{n}(2)$

Keterangan :

$\mathrm{m}=$ hasil normalisasi

$\mathrm{x}=$ nilai tiap cell $/$ gabungan antara baris dan kolom

$\mathrm{n}=$ hasil jumlah tiap kolom

Contoh perhitungan :

$\mathrm{m}=1 / 12=0.083$

$\mathrm{m}=0,5 / 7,5=0.067$

$\mathrm{m}=0.2 / 3.7=0.054$

$\mathrm{m}=0.25 / 2=0.125$

Berikut nilai normalisasi matriks yang dapat dilihat pada tabel 3 .

Tabel 3. Nilai Normalisasi Matriks

\begin{tabular}{|l|c|c|c|c|}
\hline \multicolumn{1}{|c|}{ Kriteria } & Golongan & $\begin{array}{c}\text { Eselon } \\
\text { terakhir }\end{array}$ & $\begin{array}{c}\text { Jabatan } \\
\text { terakhir }\end{array}$ & $\begin{array}{c}\text { Pendidikan } \\
\text { terakhir }\end{array}$ \\
\hline Golongan & 0.083 & 0.067 & 0.054 & 0.125 \\
\hline Eleselon terakhir & 0.167 & 0.133 & 0.135 & 0.125 \\
\hline Jabatan terakhir & 0.417 & 0.267 & 0.270 & 0.25 \\
\hline Pendidikan terakhir & 0.333 & 0.533 & 0.540 & 0.5 \\
\hline
\end{tabular}


4. Menghitung bobot prioritas

Menjumlahkan nilai-nilai dari baris dan membagi hasil jumlahnya dengan banyak jumlah elemen untuk mendapatkan nilai rata-rata/ bobot prioritas yang ditunjukkan pada persamaan di bawah ini.

$b p=\frac{\sum_{j=0}^{n} x_{i j}}{n}(3)$

Keterangan :

$\mathrm{bp}=$ hasil rata-rata/bobot prioritas

$\mathrm{n}=$ banyak kriteria

$\mathrm{j}=1,2,3, \ldots, \mathrm{n}$

$\mathrm{x}=$ nilai tiap cell $/$ gabungan antara baris dan kolom

Contoh perhitungan :

$\mathrm{bp}=0.083+\frac{0.067+0.054+0.125=0.082}{4}$

Lakukan perhitungan sampai baris ke tiga / baris Pendidikan terakhir. Berikut hasil dari penjumlahan baris dan di bagi dengan jumlah elemen/ jumlah kriteria yang dapat dilihat pada tabel 4

Tabel 4. Bobot Prioritas

\begin{tabular}{|l|c|}
\hline \multicolumn{1}{|c|}{ Kriteria } & Bobot \\
\hline Golongan & 0.082 \\
\hline Eselon terakhir & 0.14 \\
\hline Jabatan terakhir & 0.301 \\
\hline Pendidikan terakhir & 0.477 \\
\hline $\mathbf{N}$ & $\mathbf{1}$ \\
\hline
\end{tabular}

5. Menghitung Eigen maksimum

Proses pembuatan keputusan, penting untuk mengetahui seberapa baik konsistensi yang ada karena tidak diharapkan keputusan berdasarkan pertimbangan dengan konsistensi yang rendah. Hal-hal yang dilakukan dalam tahap ini adalah:

a. Kalikan setiap nilai cell pertama dengan bobot prioritas pertama, nilai pada kolom cell kedua dengan prioritas kedua, dan seterusnya.

Contoh perhitungan:

Kolom Golongan $=1 * 0.082=0.082$

Kolom Eselon $=0.5 * 0.14=0.07$

Kolom Jabatan $=0.2 * 0.301=0.060$

Kolom Pendidikan $=0.25 * 0.477=0.119$

Lakukan perhitungan sampai kolom terakhir. Berikut hasil dari perkalian setiap nilai cell dengan bobot prioritas dapat dilihat pada tabel 5 . 
Tabel 5. Perkalian Setiap Nilai Cell Dengan Bobot Prioritas

\begin{tabular}{|l|c|c|c|c|}
\hline \multicolumn{1}{|c|}{ Kriteria } & Golongan & $\begin{array}{c}\text { Eselon } \\
\text { terakhir }\end{array}$ & $\begin{array}{c}\text { Jabatan } \\
\text { terakhir }\end{array}$ & $\begin{array}{c}\text { Pendidikan } \\
\text { terakhir }\end{array}$ \\
\hline Golongan & 0.082 & 0.07 & 0.060 & 0.119 \\
\hline Eselon terakhir & 0.164 & 0.14 & 0.151 & 0.119 \\
\hline Jabatan terakhir & 0.41 & 0.28 & 0.301 & 0.238 \\
\hline $\begin{array}{l}\text { Pendidikan } \\
\text { terakhir }\end{array}$ & 0.328 & 0.56 & 0.602 & 0.477 \\
\hline
\end{tabular}

b. Jumlahkan hasilnya untuk setiap baris pada matriks.

Contoh perhitungan:

Baris Golongan $=0.082+0.07+0.060+0.119=0.331$

Lakukan perhitungan sampai baris terakhir atau baris Pendidikan terakhir. Berikut hasil penjumlahan setiap baris pada matriks dapat dilihat pada tabel 6 .

Tabel 6. Hasil Penjumlahan Setiap Baris

\begin{tabular}{|l|c|c|c|c|c|}
\hline \multicolumn{1}{|c|}{ Kriteria } & Golongan & $\begin{array}{c}\text { Eselon } \\
\text { terakhir }\end{array}$ & $\begin{array}{c}\text { Jabatan } \\
\text { terakhir }\end{array}$ & $\begin{array}{c}\text { Pendidikan } \\
\text { terakhir }\end{array}$ & Jumlah \\
\hline Golongan & 0.082 & 0.07 & 0.060 & 0.119 & 0.331 \\
\hline Eselon terakhir & 0.164 & 0.14 & 0.150 & 0.119 & 0.573 \\
\hline Jabatan terakhir & 0.41 & 0.28 & 0.301 & 0.238 & 1.229 \\
\hline $\begin{array}{l}\text { Pendidikan } \\
\text { terakhir }\end{array}$ & 0.328 & 0.56 & 0.602 & 0.477 & 1.967 \\
\hline
\end{tabular}

c. Hasil dari penjumlahan baris dibagi dengan elemen prioritas yang bersangkutan.

Contoh perhitungan:

Baris Golongan $=0.331 / 0.082=4.036$

Lakukan perhitungan sampai baris terakhir atau baris Pendidikan terakhir. Berikut hasil penjumlahan baris dibagi dengan elemen prioritas baris dapat dilihat pada tabel 7 .

Tabel 7. Hasil Penjumlahan Baris Dibagi Dengan Elemen Prioritas Baris

\begin{tabular}{|l|c|c|c|}
\hline \multicolumn{1}{|c|}{ Kriteria } & Jumlah baris & Bobot prioritas & $\boldsymbol{\lambda}$ \\
\hline Golongan & 0.331 & 0.082 & 4.037 \\
\hline Eselon terakhir & 0.573 & 0.14 & 4.093 \\
\hline Jabatan terakhir & 1.229 & 0.301 & 4.083 \\
\hline Pendidikan terakhir & 1.967 & 0.477 & 4.124 \\
\hline
\end{tabular}

d. Jumlahkan hasil lamda tiap kriteria dibagi dengan banyak elemen yang ada, hasilnya disebut $\lambda$ maz yang ditunjukkan pada persamaan dibawah ini.

$\lambda_{\text {maks }}=\frac{\sum \lambda}{n}(4)$

Keterangan:

$\lambda$ maks $=$ eigen maksimum

$\mathrm{n}=$ banyak kriteria 
Contoh perhitungan :

$$
\begin{aligned}
& \lambda=4.036+4.093+4.083+4.124=16.337 \\
& \lambda_{\text {maks }}=16.337 / 4=4.084
\end{aligned}
$$

6. Menghitung Indek Konsistensi atau Consistency Index (CI) yang ditunjukkan pada persamaan dibawah ini.

$C I=\frac{\lambda_{m a k s}-n}{n-1}(5)$

Keterangan:

$\mathrm{n}=$ banyak elemen

Contoh perhitungan:

$$
\begin{aligned}
& \mathrm{CI}=4.084-4=0.084 / 3=0.028 \\
& 4-1
\end{aligned}
$$

7. Menghitung Rasio Konsistensi atau Consistency Ratio (CR) yang ditunjukkan pada persamaan dibawah ini.

$C R=\frac{C I}{R I}(6)$

Keterangan:

$\mathrm{RI}=$ rasio indeks

$\mathrm{CR}=$ rasio konsistensi

Contoh perhitungan:

$\mathrm{CR}=0.028 / 0.90=0.031$

Nilai RI dapat dilihat ditabel 8 .

Tabel 8. Nilai Index Random

\begin{tabular}{|c|c|c|c|}
\hline $\begin{array}{c}\text { Ukuran } \\
\text { Matriks (N) }\end{array}$ & Nilai RI & $\begin{array}{c}\text { Ukuran } \\
\text { Matriks (N) }\end{array}$ & Nilai RI \\
\hline 1,2 & 0 & 9 & 1,45 \\
\hline 3 & 0,58 & 10 & 1,49 \\
\hline 4 & 0,90 & 11 & 1,51 \\
\hline 5 & 1,12 & 12 & 1,48 \\
\hline 6 & 1,24 & 13 & 1,56 \\
\hline 7 & 1,32 & 14 & 1,57 \\
\hline 8 & 1,41 & 15 & 1,59 \\
\hline
\end{tabular}

8. Memeriksa konsistensi hirarki jika nilai $\mathrm{CR}>0,1$ maka penilaian data judgement tidak konsisten dan harus diperbaiki. Jika rasio konsisten $\mathrm{CR} \leq 0,1$ maka perhitungan data konsisten dan benar.

CR $(0.031) \leq 0.1$ maka perhitungan data konsisten dan benar. 


\subsection{Metode $S A W$}

Metode SAW yaitu menentukan nilai bobot pada setiap atributnya, kemudian pada tahap selanjutnya dilakukan perengkingan yang akan menyeleksi alternatif terbaik [6]. Dalam penelitian ini metode SAW digunakan untuk perhitungan terakhir atau menentukan rangking kenaikan jabatan pada Dinas Kesehatan (Dinkes) .

Tahap-tahap dalam penyelesaian metode SAW menurut [7] adalah :

1. Menentukan kriteria-kriteria yang dijadikan acuan dalam pendukung keputusan yaitu Ci.

a. Golongan

Indikator yang digunakan dalam menentukan kenaikan jabatan berdasarkan golongan terakhir karyawan. Kriteria Golongan dapat dilihat pada tabel 9.

Tabel 9. Kriteria Golongan

\begin{tabular}{|c|c|c|}
\hline Kriteria & Range & \multicolumn{1}{c|}{ Bobot } \\
\hline \multirow{4}{*}{ Golongan } & Tidak punya golongan & Variabel ke-0 $/ 0 / 4=0$ \\
\cline { 2 - 3 } & $1 / \mathrm{a}-1 / \mathrm{d}$ & Variabel ke-1 / 1/4 =0,25 \\
\cline { 2 - 3 } & $\mathrm{II} / \mathrm{a}-\mathrm{II} / \mathrm{d}$ & Variabel ke-2 $/ 2 / 4=0,5$ \\
\cline { 2 - 3 } & $\mathrm{III} / \mathrm{a}-\mathrm{III} / \mathrm{d}$ & Variabel ke-3 $/ 3 / 4=0,75$ \\
\cline { 2 - 3 } & $\mathrm{IV} / \mathrm{A}-\mathrm{IV} / \mathrm{e}$ & Variabel ke-4 / 4/4 =1 \\
\hline
\end{tabular}

b. Eselon terakhir

Indikator yang digunakan dalam menentukan kenaikan jabatan berdasarkan eselon terakhir karyawan. Kriteria eselon terakhir dapat dilihat pada tabel 10.

Tabel 10. Kriteria Eselon Terakhir

\begin{tabular}{|l|c|c|}
\hline Kriteria & Range & Bobot \\
\hline \multirow{4}{*}{$\begin{array}{l}\text { Eselon } \\
\text { terakhir }\end{array}$} & Tidak punya eselon & Variabel ke-0 / 0/4 =0 \\
\cline { 2 - 3 } & Eselon IV & Variabel ke-1 / 1/4 =0,25 \\
\cline { 2 - 3 } & Eselon III & Variabel ke-2 / 2/4 =0,5 \\
\cline { 2 - 3 } & Eselon II & Variabel ke-3/3/4 =0,75 \\
\cline { 2 - 3 } & Eselon I & Variabel ke-4 / 4/4 =1 \\
\hline
\end{tabular}

c. Jabatan Terakhir

Indikator yang digunakan dalam menentukan kenaikan jabatan berdasarkan jabatan terkhir karyawan. Kriteria jabatan terakhir dapat dilihat pada tabel 11.

Tabel 11. Kriteria Jabatan Terakhir

\begin{tabular}{|c|c|c|}
\hline Kriteria & Range & Bobot \\
\hline \multirow{4}{*}{ Jabatan } & Tidak Punya Jabatan & Variabel ke-0 / 0/5 =0 \\
\cline { 2 - 3 } terakhir & Staff & Variabel ke-1/ 1/5 =0,2 \\
\cline { 2 - 3 } & Ka.Seksi & Variabel ke-2 / 2/5 =0,4 \\
\cline { 2 - 3 } & Ka.Bidang & Variabel ke-3/3/5 =0,6 \\
\cline { 2 - 3 } & Ka.Subbag & Variabel ke-4 / 4/5 =0,8 \\
\cline { 2 - 3 } & Sekretaris & Variabel ke-5 / 5/5 =1 \\
\hline
\end{tabular}

d. Pendidikan Terakhir

Indikator yang digunakan dalam menentukan kenaikan jabatan berdasarkan pendidikan terakhir karyawan. Kriteria pendidikan terakhir dapat dilihat pada tabel 12. 
Tabel 12. Kriteria Pendidikan Terakhir

\begin{tabular}{|c|c|c|}
\hline Kriteria & Range & Bobot \\
\hline \multirow{3}{*}{$\begin{array}{l}\text { Pendidikan } \\
\text { Terakhir }\end{array}$} & SMA & Variabel ke-0/0/3=0 \\
\cline { 2 - 3 } & D3 - Sederajat & Variabel ke-1/1/3=0,33 \\
\cline { 2 - 3 } & S1 - Sederajat & Variabel ke-2/2/3=0,67 \\
\cline { 2 - 3 } & S2 & Variabel ke-3/3/3 =1 \\
\hline
\end{tabular}

Ditentukan berdasarkan persyaratan utama atau kriteria-kriteria diatas, selanjutnya bobot preferensi (W) yang didapat pada perhitungan bobot menggunakan metode AHP sebagai berikut:

$\mathrm{W} 1=$ Golongan $=0,082$

$\mathrm{W} 2=$ Eselon terakhir $=0,14$

W3 $=$ Jabatan terakhir $=0,301$

$\mathrm{W} 3=$ Pendidikan terakhir $=0,476$

Dalam penentuan kenaikan jabatan dengan menggunakan metode AHP dan SAW berdasarkan kriteria-kriteria diatas maka diperoleh data dapat dilihat pada tabel 13.

Tabel 13. Nilai dari masing-masing kriteria

\begin{tabular}{|c|c|c|c|c|c|}
\hline No & Nama & Golongan & Eselon & Jabatan & Pendidikan \\
\hline 1 & Badarudin & IV/a & Eselon III & Staff & S2 \\
\hline 2 & Anita & III/d & Eselon IV & Staff & S1 \\
\hline 3 & Sumarman & III/d & Eselon IV & Staff & S2 \\
\hline 4 & Deddy & III/c & Eselon IV & Staff & S1 \\
\hline 5 & Erdha & III/c & Eselon IV & Staff & S1 \\
\hline
\end{tabular}

2. Menentukan rating kecocokan setiap alternatif pada setiap kriteria.

Dalam menentukan rating kecocokan maka nilai dari masing-masing kriteria dimasukkan kedalam tabel rating kecocokan yang telah disesuaikan dengan nilai dari tabel kriteria. Maka tabel rating kecocokan dapat dilihat pada tabel 14.

Tabel 14. Rating Kecocokan

\begin{tabular}{|c|c|c|c|c|c|}
\hline \multirow{2}{*}{ No } & \multirow{2}{*}{ Nama } & \multicolumn{4}{|c|}{ Kriteria } \\
\cline { 3 - 6 } & & Golongan & Eselon & Jabatan & Pendidikan \\
\hline 1 & Badarudin & 1 & 0,5 & 0,2 & 1 \\
\hline 2 & Anita & 0,75 & 0,25 & 0,2 & 0,67 \\
\hline 3 & Sumarman & 0,75 & 0,25 & 0,2 & 1 \\
\hline 4 & Deddy & 0,75 & 0,25 & 0,2 & 0,67 \\
\hline 5 & Erdha & 0,75 & 0,25 & 0,2 & 0,67 \\
\hline
\end{tabular}

3. Membuat matriks keputusan berdasarkan kriteria (Ci).

Nilai dari hasil tabel kecocokan kemudian dibuat kedalam bentuk matriks.

$$
X\left[\begin{array}{cccc}
1 & 0,5 & 0,2 & 1 \\
0,75 & 0,25 & 0,2 & 0,67 \\
0,75 & 0,25 & 0,2 & 1 \\
0,75 & 0,25 & 0,2 & 0,67 \\
0,75 & 0,25 & 0,2 & 0,67
\end{array}\right]
$$


4. Kemudian melakukan normalisasi matriks berdasarkan persamaan yang disesuaikan dengan jenis atribut (atribut keuntungan maupun atribut biaya) sehingga diperoleh matriks ternormalisasi R.

a. Kriteria Golongan

$$
\begin{gathered}
R_{11}=\frac{1}{\operatorname{Max}(1,0,75,0,75,0,75,0,75)}=\frac{1}{1}=1 \\
R_{21}=\frac{0,75}{\operatorname{Max}(1,0,75,0,75,0,75,0,75)}=\frac{0,75}{1}=0,75 \\
R_{31}=\frac{0,75}{\operatorname{Max}(1,0,75,0,75,0,75,0,75)}=\frac{0,75}{1}=0,75 \\
R_{41}=\frac{0,75}{\operatorname{Max}(1,0,75,0,75,0,75,0,75)}=\frac{0,75}{1}=0,75 \\
R_{51}=\frac{0,75}{\operatorname{Max}(1,0,75,0,75,0,75,0,75)}=\frac{0,75}{1}=0,75
\end{gathered}
$$

b. Kriteria Eselon terakhir

$$
\begin{gathered}
R_{12}=\frac{0,5}{\operatorname{Max}(0,5,0,25,0,25,0,25,0,25)}=\frac{0,5}{0,5}=1 \\
R_{22}=\frac{0,25}{\operatorname{Max}(0,5,0,25,0,25,0,25,0,25)}=\frac{0,25}{0,5}=0,5 \\
R_{32}=\frac{0,25}{\operatorname{Max} \operatorname{Max}(0,5,0,25,0,25,0,25,0,25)}=\frac{0,25}{0,5}=0,5 \\
R_{42}=\frac{0,25}{\operatorname{Max}(0,5,0,25,0,25,0,25,0,25)}=\frac{0,25}{0,5}=0,5 \\
R_{52}=\frac{0,25}{\operatorname{Max}(0,5,0,25,0,25,0,25,0,25)}=\frac{0,25}{0,5}=0,5
\end{gathered}
$$

c. Kriteria Jabatan terakhir

$$
\begin{aligned}
& R_{13}=\frac{0,2}{\operatorname{Max}(0,2,0,2,0,2,0,2,0,2)}=\frac{0,2}{0,2}=1 \\
& R_{23}=\frac{0,2}{\operatorname{Max}(0,2,0,2,0,2,0,2,0,2)}=\frac{0,2}{0,2}=1 \\
& R_{33}=\frac{0,2}{\operatorname{Max}(0,2,0,2,0,2,0,2,0,2)}=\frac{0,2}{0,2}=1 \\
& R_{43}=\frac{0,2}{\operatorname{Max}(0,2,0,2,0,2,0,2,0,2)}=\frac{0,2}{0,2}=1 \\
& R_{53}=\frac{0,2}{\operatorname{Max}(0,2,0,2,0,2,0,2,0,2)}=\frac{0,2}{0,2}=1
\end{aligned}
$$

d. Kriteria Pendidikan terakhir

$$
\begin{gathered}
R_{14}=\frac{1}{\operatorname{Max}(1,0,67,1,0,67,0,67)}=\frac{1}{1}=1 \\
R_{24}=\frac{0,67}{\operatorname{Max}(1,0,67,1,0,67,0,67)}=\frac{0,67}{1}=0,67 \\
R_{34}=\frac{1}{\operatorname{Max}(1,0,67,1,0,67,0,67)}=\frac{1}{1}=1
\end{gathered}
$$




$$
\begin{aligned}
& R_{44}=\frac{0,67}{\operatorname{Max}(1,0,67,1,0,67,0,67)}=\frac{0,67}{1}=0,67 \\
& R_{54}=\frac{0,67}{\operatorname{Max}(1,0,67,1,0,67,0,67)}=\frac{0,67}{1}=0,67
\end{aligned}
$$

Dari perhitungan diatas diperoleh matriks R sebagai berikut:

$$
R\left[\begin{array}{cccc}
1 & 1 & 1 & 1 \\
0,75 & 0,5 & 1 & 0,67 \\
0,75 & 0,5 & 1 & 1 \\
0,75 & 0,5 & 1 & 0,67 \\
0,75 & 0,5 & 1 & 0,67
\end{array}\right]
$$

5. Hasil akhir diperoleh dari proses perangkingan yaitu penjumlahan dari perkalian matriks ternormalisasi $\mathrm{R}$ dengan vector bobot sehingga diperoleh nilai terbesar yang dipilih sebagai alternatif terbaik (Ai) sebagi solusi.

$$
\begin{aligned}
\mathrm{V}_{1} & =(1 * 0.082)+(1 * 0,14)+(1 * 0,301)+(1 * 0,477) \\
& =0,082+0,14+0,301+0,476=1 \\
\mathrm{~V}_{2} & =(0,75 * 0,082)+(0,5 * 0,14)+(1 * 0,301)+(0,67 * 0,477) \\
& =0,061+0,07+0,301+0,319=0,75 \\
\mathrm{~V}_{3} & =(0,75 * 0,082)+(0,5 * 0,14)+(1 * 0,301)+(1 * 0,477) \\
& =0,061+0,07+0,301+0,477=0,91 \\
\mathrm{~V}_{4} & =(0,75 * 0,082)+(0,5 * 0,14)+(1 * 0,301)+(0,67 * 0,477) \\
& =0,061+0,07+0,301+0,319=0,75 \\
\mathrm{~V}_{5} & =(0,75 * 0,082)+(0,5 * 0,14)+(1 * 0,301)+(0,67 * 0,477) \\
& =0,061+0,07+0,301+0,319=0,75
\end{aligned}
$$

Dari setiap perhitungan nilai $\mathrm{V}_{1}$ dari setiap karyawan yang akan mendapatkan kenaikan jabatan maka dibuatkan tabel penentuan rangking dapat dilihat pada tabel 15.

Tabel 15. Penentuan Rangking

\begin{tabular}{|c|c|c|c|c|}
\hline No & Ai & Nama & Nilai & Rangking \\
\hline 1 & $\mathrm{~V}_{1}$ & Badarudin & 1 & 1 \\
\hline 2 & $\mathrm{~V}_{3}$ & Sumarman & 0,91 & 2 \\
\hline 3 & $\mathrm{~V}_{2}$ & Anita & 0,75 & 3 \\
\hline 4 & $\mathrm{~V}_{4}$ & Deddy & 0,75 & 4 \\
\hline 5 & $\mathrm{~V}_{5}$ & Erdha & 0,75 & 5 \\
\hline
\end{tabular}

Dari penentuan rangking diatas, maka yang akan naik jabatan adalah Badarudin yang mendapatkan rangking pertama (1).

\section{HASIL DAN PEMBAHASAN}

Uji akurasi ini dilakukan dengan mencocokan hasil dari Aplikasi Penentuan Kenaikan Jabatan Karyawan dengan data yang didapatkan dari perusahaan, dan dengan membuktikan metode AHP saja, metode SAW saja dan metode AHP \& SAW.. Pengujian akurasi ini bertujuan untuk mengetahui seberapa banyak kecocokan antara data hasil keputusan sistem dengan data 
hasil keputusan perusahaan, banyaknya kecocokan akan menentukan tingkat akurasi sistem [8]. Rumus perhitungan akurasi menggunakan persamaan dibawah ini.

$$
\text { Akurasi }=\frac{\text { jumlah data yang sama }}{\text { jumlah seluruh data }} \times 100 \%(7)
$$

1. Pengujian Hasil Akurasi Kasus 1

Tabel 16. Pengujian Hasil Akurasi Kasus 1

\begin{tabular}{|c|c|c|c|c|c|c|}
\hline No & Nama & NIP & Riil & AHP & SAW & AHP \& SAW \\
\hline 1 & H.Badaruddin & 196302111985031007 & 1 & 8 & 1 & 1 \\
\hline 2 & Sumaman & 197601062005011008 & 2 & 7 & 2 & 2 \\
\hline 3 & Anita Rianita & 197608281999032002 & 3 & 6 & 3 & 3 \\
\hline 4 & Deddy A. & 197601112006041005 & 4 & 5 & 4 & 4 \\
\hline 5 & Erdha Y. & 197506192000032002 & 5 & 4 & 5 & 5 \\
\hline 6 & Msy.Muharlina & 197003091991032004 & 6 & 3 & 6 & 6 \\
\hline 7 & Jumantoro & 196107141983021001 & 7 & 2 & 7 & 7 \\
\hline 8 & Hidayat Tulher & 196006291984031002 & 8 & 1 & 8 & 8 \\
\hline
\end{tabular}

2. Pengujian Hasil Akurasi Kasus 2

Tabel 17. Pengujian Hasil Akurasi Kasus 2

\begin{tabular}{|c|c|c|c|c|c|c|}
\hline No & Nama & NIP & Riil & AHP & SAW & AHP \& SAW \\
\hline 1 & Aprilia N. & 197704252009022007 & 1 & 1 & 1 & 1 \\
\hline 2 & Tiarman A. & 198104182006041003 & 2 & 2 & 2 & 2 \\
\hline 3 & Rohana & 196012151984092001 & 3 & 3 & 3 & 3 \\
\hline 4 & Farida Aryani & 196002071984012002 & 4 & 4 & 4 & 4 \\
\hline 5 & Erika & 196805011990032007 & 5 & 5 & 5 & 5 \\
\hline 6 & Suryani & 197503061997032001 & 6 & 6 & 6 & 6 \\
\hline 7 & Dekvita Ara & 198010212005042002 & 7 & 7 & 7 & 7 \\
\hline 8 & Iskandar & 196505301983121001 & 8 & 8 & 8 & 8 \\
\hline
\end{tabular}

3. Pengujian Hasil Akurasi Kasus 3

Tabel 18. Pengujian Hasil Akurasi Kasus 3

\begin{tabular}{|c|c|c|c|c|c|c|}
\hline No & Nama & NIP & Riil & AHP & SAW & AHP \& SAW \\
\hline 1 & Hemalia H. & 196409242002122001 & 1 & 8 & 2 & 2 \\
\hline 2 & Ulil Azmi & 197104261992031004 & 2 & 7 & 3 & 3 \\
\hline 3 & Ismawati & 196203151988032002 & 3 & 6 & 4 & 4 \\
\hline 4 & Agustian & 197108271994011001 & 4 & 3 & 1 & 1 \\
\hline 5 & Andi Susanto & 197509102009021003 & 5 & 4 & 5 & 5 \\
\hline 6 & Yuliana Darlis & 198607032009022006 & 6 & 5 & 6 & 6 \\
\hline 7 & Riduana & 196201011983032013 & 7 & 2 & 7 & 7 \\
\hline 8 & Darwin & 196204111983121001 & 8 & 1 & 8 & 8 \\
\hline
\end{tabular}


4. Hasil Perhitungan Akurasi

Tabel 19. Hasil Perhitungan Akurasi

\begin{tabular}{|c|c|c|c|}
\hline No & AHP & SAW & AHP \& SAW \\
\hline Kasus 1 & $0 \%$ & $100 \%$ & $100 \%$ \\
\hline Kasus 2 & $0 \%$ & $100 \%$ & $100 \%$ \\
\hline Kasus 3 & $0 \%$ & $50 \%$ & $50 \%$ \\
\hline
\end{tabular}

Berdasarkan hasil perhitungan akurasi dari 3 kasus tersebut maka yang mendekati perhitungan manual dari Dinas Kesehatan adalah hasil perhitungan menggunakan metode AHP \& SAW dan metode SAW. Namun pada penggunaan metode SAW penentuan kenaikan jabatan karyawan mengharuskan admin/pengguna memasukkan nilai bobot, sedangkan metode AHP \& SAW admin/pengguna tidak perlu memasukkan nilai bobot karena nilai bobot otomatis dihitung menggunakan metode AHP.

\section{KESIMPULAN}

Berdasarkan hasil yang diperoleh dapat disimpulkan, yaitu:

1. Sistem pendukung keputusan penentuan kenaikan jabatan bagi karyawan pada Dinas Kesehatan dengan menggunakan metode AHP dan SAW ini dapat membantu perusahaan dalam mengambil keputusan.

2. Metode AHP dan SAW dapat menghasilkan rekomendasi kenaikan jabatan karyawan sesuai dengan kebutuhan dan beradasarkan kriteria yang telah ditentukan. Hasil pengujian akurasi pada 3 kasus uji diperoleh, untuk pengujian kasus 1 hasil metode AHP \& SAW adalah $100 \%$, hasil metode AHP adalah 0\% dan hasil metode SAW adalah $100 \%$. Untuk pengujian kasus 2 hasil metode AHP \& SAW adalah 100\%, hasil metode AHP adalah 0\% dan hasil metode SAW adalah 100\%. Sedangkan pengujian pada kasus 3 hasil metode AHP \& SAW adalah 50\%, hasil metode AHP adalah 0\% dan hasil metode SAW adalah 50\%.

\section{SARAN}

Saran yang dapat diberikan untuk pengembangan sistem adalah melakukan perbandingan penggunaan kombinasi metode AHP dan SAW dengan kombinasi metode sistem pendukung keputusan yang lain dalam kasus penentuan kenaikan jabatan untuk memperoleh kombinasi metode yang memiliki akurasi lebih baik.

\section{UCAPAN TERIMA KASIH}

Penulis mengucapkan terima kasih kepada papa Safrizal dan mama Darmaini yang telah memberi dukungan financial terhadap penelitian ini. 


\section{DAFTAR PUSTAKA}

[1] Mya. Riska. Fitriyani. 2017, "Sistem Pendukung Keputusan untuk Kenaikan Jabatan Aparatur Negara Sipil Stuktural pada Badan Kabupaten Lampung Tengan dengan Metode $S A W, "$

[2] A. E. Munthafa and H. Mubarok. 2017, "Penerapan Metode Analytical Hierarchy Process Dalam Sistem,” J. Siliwangi, Vol. 3, No. 2, pp. 192-201.

[3] M. Setya and D. Utomo. 2015, "Penerapan Metode SAW ( Simple Additive Weight) pada Sistem Pendukung Keputusan untuk Pemberian Beasiswa pada SMA Negeri 1 Cepu Jawa Tengah,” Fak. Ilmu Komput. Univ. Dian Nuswantoro, Semarang.

[4] N. N. Satriani, I. Cholissodin, and M. A. Fauzi. 2018, "Sistem Pendukung Keputusan Penentuan Calon Penerima Beasiswa BBP- PPA Menggunakan Metode AHPPROMETHEE I Studi Kasus: FILKOM Universitas Brawijaya,” Vol. 2, No. 7, pp. 27802788.

[5] Alit. 2014, "Sistem Penunjang Keputusan Pemilihan Jurusan di SMA Islam Sudirman Ambara Menggunakan Metode AHP,"

[6] A. Faizin and E. Mulyanto. 2015, "Penerapan Metode Simple Additive Weighting ( SAW ) untuk Seleksi Tenaga Kerja Baru Bagian Produksi ( Studi Kasus Pada PT . Jesi Jason Surja Wibowo )," Univ. Dian Nuswantoro Semarang, pp. 1-9.

[7] Frieyadie 2016, "Peneraan Metode SAW Dalam Sistem Pendukung Keputusan Promosi Kenaikan Jabatan,” Vol. XII, No. 1, pp. 37-45.

[8] M. Rendra, H. Roisdiansyah, A. W. Widodo, and N. Hidayat. 2017, "Sistem Pendukung Keputusan untuk Pemilihan Penanaman Varietas Unggul Padi Menggunakan Metode AHP dan TOPSIS," Vol. 1, No. 10, pp. 1058-1065. 